American Journal of Animal and Veterinary Sciences 6 (3): 112-116, 2011

ISSN 1557-4555

(C) 2011 Science Publications

\title{
Efficacy of Closantel 5\% Against Cattle Gastrointestinal Parasites
}

\author{
${ }^{1}$ Y. Garedaghi, ${ }^{2}$ A.P. Rezaii Saber and ${ }^{3}$ R. Attaremadraki \\ ${ }^{1}$ Department of Pathobiology, \\ ${ }^{2}$ Department of Clinical Sciences, \\ ${ }^{3}$ Post Graduated Student of Veterinary Medicine, \\ Tabriz Branch, Islamic Azad University, Tabriz, Iran
}

\begin{abstract}
Problem statement: There are several anthelmintic classes based on chemical structure that are in use, but, during the last 20 years, it has been increasingly noted that the target parasites have become resistant, the incidence varying with geographical location and mode of use. Approach: In this study, 60 apparently healthy cows under the same management conditions of the experiment, feces (EPG) were examined. Cows divided to 2 groups $(30=$ control, $30=$ treated with closantel $5 \%)$ then treated cows received $10 \mathrm{mg} \mathrm{kg}^{-1} \mathrm{~B} . \mathrm{W}$ closantel $5 \%$ oraly and After treatment the cow, faecal samples from each of 2 groups were examined in days 1-7-21-28 after treatment by wet-mount and willismethods and MC-master slid used for egg count. Results: Therefore Closantel 5\% drugs if used oraly by dosage $1 \mathrm{~mL} 10 \mathrm{~kg}^{-1}$ B.W in cow against Fasciola hepatica and Haemonchus spp. Bunostomum phlebotomum been quite effective (average percentage of drug effect $=97 \%$ ) and used for control and prevention of parasitic infections in cow was recommended. Conclusion: Therefore Closantel 5\% is an effective drug against cattle gastrointestinal helminthes in Iran.
\end{abstract}

Key words: Helminth parasites, several anthelmintic, plasma concentration, pharmacokinetic profiles, Bunostomum phlebotomum, closantel affects

\section{INTRODUCTION}

Anthelmintics are used extensively to control helminth parasites in animals and are especially useful in domestic farm livestock and those species that graze on pasture and inevitably ingest the infective stages of the parasites. There are several anthelmintic classes based on chemical structure that are in use, but, during the last 20 years, it has been increasingly noted that the target parasites have become resistant, the incidence varying with geographical location and mode of use. One proposed method of delaying the development of resistance is to combine two drugs with similar spectra of activity but with different modes of action (Baggot and McKellar, 1994; Barnes et al., 1995; Lifschitz et al., 2004; Lo et el., 1985 and El-Nabarawy et al., 2010). In addition, combinations of drugs can sometimes be used in conjunction with the knowledge of local epidemiology of parasites to reduce the frequency of treatment and further reduce exposure of the worms to the anthelmintics. It has been shown that the clinical effectiveness of anthelmintics is closely related to their pharmacokinetic profiles (Bassisi et al., 2004; Bogan and McKellar, 1988; Toutain et al., 1988; Craven et al., 2002).
Plasma availability can be affected by the formulation and route of administration.

Lanusse and Prichard (1993) noted that slight modifications to plasma concentration can have a large effect on the persistence and availability of avermectins such as ivermectin.

Ivermectin affects nematodes, whereas closantel, a salicylanilide, affects both blood-feeding nematodes and trematodes. The pharmacokinetics of ivermectin have been extensively reported in ruminants (Degroodt et al., 1994; Fairweather and Boray, 1999; EAVPT, 1986; Michiels et al., 1987), as have those of closantel (Vercruysse and Rew, 2002; Lanusse and Prichard, 1993; Montenegro et al., 2003; Lanusse et al., 1997; Mohammed-Ali and Bogan, 1987; Edem and Usoh, 2009; Akinnuga et al., 2010). Recently a novel product combining closantel and ivermectin in a single formulation has been developed and licensed for use in cattle. In order to ensure that the product can be expected to possess the same efficacy against sensitive helminths as those products licensed in singleconstituent formulations, it is necessary to establish that the pharmacokinetic profiles of ivermectin and closantel are not altered in the formulated dual component product (Lifschitz et al.,

Corresponding Author: Y. Garedaghi, Department of Pathobiology, Islamic Azad University, Tabriz Branch, Tabriz, Iran Tel: 00989143110499 
1999a; 1999b; Sallovitz et al., 2002; Toutain et al., 1997; Toutain and Koritz, 1997).

\section{MATERIALS AND METHODS}

In this study, 60 apparently healthy cows under the same management conditions of the experiment, feces (EPG) were examined. After determining the contamination of the animals after 3 stages feces samples examination they were randomly divided into 2 categories, 30 were immovable.

The first group (control) 30 head and did not receive any drug as only two other times in the stool were tested and the control group with normal saline for oral dosage form were studied simultaneously.

The second group is the treatment group and 30 head of livestock were studied by the drug closantel $5 \%$ were treated with oral doses $1 \mathrm{~mL} 10 \mathrm{~kg}^{-1} \mathrm{~B}$.W conceived.

After treatment the cow, faecal samples from each of 2 groups were examined in days 1-7-21-28 after treatment. For fecal samples examination the wet method (Wet-mount) and Willis (willis-method) and for egg counts of Nematoda (EPG) the Mc-Master slide (MC-master method) was used.

According to the formula of $5 \%$ closantel effects on different days after treatment were evaluated:

Effects of Drug $=\frac{100 \times \mathrm{R}\left(\begin{array}{l}\text { mean number of eggs per gram } \\ \text { of feces in the treated group }\end{array}\right)-\mathrm{p}}{\mathrm{P}\left(\begin{array}{l}\text { mean number of eggs per gram of feces in } \\ \text { the control group }\end{array}\right)}$

\section{RESULTS}

Results of this study are set based on the Table 1-5.

Table 1: Mean number of eggs per gram of feces in case and control groups before treatment and groups divided

Egg Per Gram of feces (EPG)

\begin{tabular}{lllll} 
Total & $\begin{array}{l}\text { Bunostomum } \\
\text { phlebotomum }\end{array}$ & $\begin{array}{l}\text { Haemonchus } \\
\text { spp. }\end{array}$ & $\begin{array}{l}\text { Fasciola } \\
\text { hepatica }\end{array}$ & \\
\hline 2009 & 543 & 781 & 685 & Frequency \\
100 & 27 & $35 / 6$ & $34 / 1$ & Percent \\
\hline
\end{tabular}

Table 2: Compares the number of eggs per gram of feces in different parasites one-day after treatment, according to study groups

\begin{tabular}{|c|c|c|c|c|c|c|c|c|}
\hline \multirow{3}{*}{$\frac{\mathrm{p}}{0 / 02}$} & \multirow{3}{*}{$\frac{x^{2}}{7 / 07}$} & \multirow{4}{*}{$\begin{array}{r}\text { Total } \\
1392 \\
100\end{array}$} & \multicolumn{3}{|c|}{ Egg Per Gram of feces (EPG) } & \multirow{2}{*}{\multicolumn{3}{|c|}{ One-day after treatment }} \\
\hline & & & \multirow{2}{*}{$\begin{array}{l}\begin{array}{l}\text { Bunostomит } \\
\text { phlebotomum }\end{array} \\
410\end{array}$} & \multirow{2}{*}{$\begin{array}{l}\text { Haemonchus } \\
\text { spp. }\end{array}$} & $\begin{array}{l}\text { Fasciola } \\
\text { hepatica }\end{array}$ & & & \\
\hline & & & & & 421 & Frequency & Treated & Group \\
\hline & & & $29 / 5$ & $40 / 3$ & $30 / 2$ & Percent & & \\
\hline & & 2154 & 607 & 804 & 743 & Frequency & Control & \\
\hline & & 100 & $28 / 2$ & $37 / 3$ & $34 / 5$ & Percent & & \\
\hline & & 3546 & 1017 & 1365 & 1164 & Frequency & Total & \\
\hline & & 100 & $28 / 7$ & $38 / 5$ & $32 / 8$ & Percent & & \\
\hline
\end{tabular}

Table 3: Compares the number of eggs per gram of feces in different parasites 7-day after treatment, according to study groups

\begin{tabular}{|c|c|c|c|c|c|c|c|c|}
\hline \multirow{3}{*}{$\frac{\mathrm{p}}{0 / 000}$} & \multirow{3}{*}{$\begin{array}{l}x^{2} \\
601 / 28\end{array}$} & \multirow{4}{*}{$\begin{array}{r}\text { Total } \\
710 \\
100\end{array}$} & \multicolumn{3}{|c|}{ Egg Per Gram of feces (EPG) } & & & \\
\hline & & & \multirow{2}{*}{$\begin{array}{l}\begin{array}{l}\text { Bunostomum } \\
\text { phlebotomum }\end{array} \\
126\end{array}$} & \multirow{2}{*}{$\begin{array}{l}\text { Haemonchus } \\
\text { spp. } \\
280\end{array}$} & \multirow{2}{*}{$\begin{array}{l}\text { Fasciola } \\
\text { hepatica }\end{array}$} & \multicolumn{3}{|c|}{ 7-day after treatment } \\
\hline & & & & & & Frequency & Treated & Group \\
\hline & & & $17 / 7$ & $39 / 4$ & $42 / 8$ & Percent & & \\
\hline & & 2149 & 591 & 793 & 765 & Frequency & Control & \\
\hline & & 100 & $27 / 5$ & $36 / 9$ & $35 / 6$ & Percent & & \\
\hline & & 2859 & 717 & 1073 & 1069 & Frequency & Total & \\
\hline & & 100 & $25 / 1$ & $37 / 5$ & $37 / 4$ & Percent & & \\
\hline
\end{tabular}

Table 4: Compares the number of eggs per gram of feces in different parasites 21-day after treatment, according to study groups

\begin{tabular}{|c|c|c|c|c|c|c|c|c|}
\hline \multirow{3}{*}{$\frac{\mathrm{p}}{0 / 039}$} & \multirow{3}{*}{$\frac{x^{2}}{6 / 48}$} & \multirow{4}{*}{$\begin{array}{r}\text { Total } \\
290\end{array}$} & \multicolumn{3}{|c|}{ Egg Per Gram of feces (EPG) } & \multirow{2}{*}{\multicolumn{3}{|c|}{ 21-day after treatment }} \\
\hline & & & \multirow{2}{*}{$\begin{array}{l}\text { Bunostoтит } \\
\text { Phlebotomum } \\
74\end{array}$} & \multirow{2}{*}{$\begin{array}{l}\text { Haemonchus } \\
\text { spp. }\end{array}$} & \multirow{2}{*}{$\begin{array}{l}\text { Fasciola } \\
\text { Hepatica } \\
92\end{array}$} & & & \\
\hline & & & & & & Frequency & Treated & Group \\
\hline & & & $25 / 5$ & $42 / 8$ & $31 / 7$ & Percent & & \\
\hline & & 1911 & 612 & 689 & 610 & Frequency & Control & \\
\hline & & 100 & 32 & $36 / 1$ & $31 / 9$ & Percent & & \\
\hline & & 2201 & 686 & 813 & 702 & Frequency & Total & \\
\hline & & 100 & $31 / 2$ & $36 / 9$ & $31 / 9$ & Percent & & \\
\hline
\end{tabular}


American J. Animal \& Vet. Sci., 6 (3): 112-116, 2011

Table 5: Compares the number of eggs per gram of feces in different parasites 28-day after treatment, according to study groups

\begin{tabular}{|c|c|c|c|c|c|c|c|}
\hline \multirow{3}{*}{$\frac{\mathrm{p}}{267 / 0}$} & \multirow{3}{*}{$\begin{array}{l}x^{2} \\
64 / 2\end{array}$} & \multirow{3}{*}{$\begin{array}{r}\text { Total } \\
54\end{array}$} & \multicolumn{2}{|c|}{ Egg Per Gram of feces (EPG) } & \multirow[b]{2}{*}{$\begin{array}{l}\text { Fasciola } \\
\text { hepatica }\end{array}$} & & \multirow[b]{2}{*}{ 28-day after treatment } \\
\hline & & & \multirow{2}{*}{$\begin{array}{l}\begin{array}{l}\text { Bunostoтит } \\
\text { phlebotomum }\end{array} \\
12\end{array}$} & $\begin{array}{l}\text { Haemonchus } \\
\text { spp. }\end{array}$ & & & \\
\hline & & & & 19 & 23 & Frequency & Treated \\
\hline & & 100 & $22 / 2$ & $35 / 2$ & $42 / 6$ & Percent & \\
\hline & & 2074 & 634 & 753 & 687 & Frequency & control \\
\hline & & 100 & $30 / 6$ & $36 / 3$ & $33 / 1$ & Percent & \\
\hline & & 2128 & 646 & 772 & 710 & Frequency & Total \\
\hline & & 100 & $30 / 4$ & $36 / 3$ & $33 / 4$ & Percent & \\
\hline
\end{tabular}

\section{DISCUSSION}

According to the chi-square test and the test results based on the difference between the two communities can be seen that the efficacy percentage of control and test groups except Haemonchus spp. parasite control (First day after treatment) is not significant ( $p>0 / 05)$.

But the efficacy of oral drugs closantel $5 \%$ solids horizons and control of parasites in the days before and after treatment than the control group is quite significant ( $p$ $<0 / 001$ ) indicate that this positive effect on drug control and The test is in control of parasitic eggs.

Uppal et al. (1993) and Costa et al. (2006) efficacy of closantel on Haemonchus spp. 100\% have been reported in India, which is partially consistent with the results of this study.

Mooney et al. (2009) and Echevarria et al. (1996) efficacy of closantel on sheeps Fasciola hepatica in Ireland in 14 days after treatment by counting Eggs Per Gram of cow feces (EPG) have reported up to 100\% which is consistent with the results of this study .

Mwamachi et al. (1995) and Sivaraj et al. (1994) in Kenya efficacy of closantel on Bunostomum 52\% in cows have reported that no consistent with the results of this study and efficacy of closantel on cows Bunostomum in iran is higher.

Al-Qudah et al. (1999) and Guerrero and Michael (1983) in Jordan the efficacy of albendazole + closantel on Haemonchus 100\% and Fasciola hepatica $77 \%$ have been reported in camels.

Stromberg et al. (1985) in sheeps that infected with the Fascioloides efficacy rate of oral closantel 95-98 percent have been reported.

\section{CONCLUSION}

Closantel 5\% drugs if used oraly by dosage $1 \mathrm{~mL}$ $10 \mathrm{~kg}^{-1}$ B.W in cow against Fasciola hepatica and Haemonchus spp., Bunostomum phlebotomum been quite effective (average percentage of drug effect $=$ 97\%) and used for control and prevention of parasitic infections in cow is recommended.

\section{ACKNOWLEDGEMENT}

The researchers highly appreciate to drug companies for their whole hearted cooperation and financial supports for the present study. The authors declare that they have no conflict of interests.

\section{REFERENCES}

Akinnuga, A.M., O. Bamidele, O.A.B. Ebunlomo, O.S. Adeniyi and G.S. Adeleyea et al., 2010. Hypoglycaemic effects of dietary intake of ripe and unripe lycopersicon esculentum (tomatoes) on streptozotocin-induced diabetes mellitus in rats. OnLine J. Biol. Sci., 10: 50-53. DOI: 10.3844/ojbsci.2010.50.53

Al-Qudah, K.M., L.A. Sharif, O.F. Al-Rawashdeh and F.K. Al-Ani, 1999. Efficacy of closantel plus albendazole liquid suspension against natural infection of gastrointestinal parasites in camels. Vet. Parasitol., 2: 173-178. DOI: 10.1016/S03044017(99)00010-2

Baggot, J.D. and Q.A. McKellar, 1994. The absorption, distribution and elimination of anthelmintic drugs: The role of pharmacokinetics. J. Vet. Pharmacol. Ther., 17: 409-419. DOI: 10.1111/j.13652885.1994.tb00271.x PMID: 7707485

Barnes, E.H., R.J. Dobson and I.A. Barger, 1995. Worm control and anthelmintic resistance: Adventures with a model. Parasitol. Today, 11: 5663. DOI: 10.1016/0169-4758(95)80117-0 PMID: 15275374

Bassisi, M.F., M. Alvinerie and A. Lespine, 2004. Macrocyclic lactones: Distribution in plasma lipoproteins of several animal species including humans. Compa. Biochem. Physiol. Part C: Toxicol. Pharmacol., 138: 437-444. DOI: 10.1016/j.cca.2004.07.011

Bogan, J.A. and Q.A. McKellar, 1988. The pharmacodynamics of ivermectin in sheep and cattle. J. Vet. Pharm. Ther., 11: 260-268. DOI: 10.1111/j.1365-2885.1988.tb00151.x 
Costa, C.T.C., C.M.L. Bevilaqua, M.V. Maciel, A.L.F. Camurca-Vasconcelos and S.M. Morais et al., 2006. Anthelmintic activity of Azadirachta indica A. Juss against sheep gastrointestinal nematodes. Vet. Parasitol., 3: 306-310. DOI: 10.1016/j.vetpar.2006.01.002

Craven, J., H. Bjorn, D.R. Hennessy and C. Friis, 2002. The effects of body composition on the pharmacokinetics of subcutaneously injected ivermectin and moxidectin in pigs. J. Vet. Pharmacol. Ther., 25: 227-232. DOI: 10.1046/j.1365-2885.2002.00400.x PMID: 12081618

Degroodt, J.M., B.W.D. Bukanski and S. Srebrnik, 1994. Determination of ivermectin residues in meat and liver by HPLC and fluorometric detection. J. Liquid Chrom., 17: 1419-1426. DOI: 10.1080/10826079408013774

EAVPT, 1986. Comparative Veterinary Pharmacology, Toxicology and Therapy: Invited Lectures. 1st Edn., MTP Press, Lancaster, ISBN: 0852009321, pp: 538.

Echevarria, F., M.F.S. Borba, A.C. Pinheiro, P.J. Waller and J.W. Hansen, 1996. The prevalence of anthelmintic resistance in nematode parasites of sheep in southern latin America: Brazil. Vet. Parasitol., 62: 199-206. DOI: 10.1016/03044017(95)00906-X

Edem, D.O. and I. F. Usoh, 2009. Biochemical changes in wistar rats on oral doses of mistletoe (Loranthus micranthus). Am. J. Pharmacol. Toxicol., 4: 94-97. DOI: 10.3844/ajptsp.2009.94.97

El-Nabarawy, S.K., M.A.E. Mohamed, M.M. Ahmed and G.H. El-Arabi, 2010. $\alpha$-lipoic acid therapy modulates serum levels of some trace elements and antioxidants in type 2 diabetic patients. Am. J. Pharmacol. Toxicol., 5: 152-158. DOI: 10.3844/ajptsp.2010.152.158

Fairweather, I. and J.C. Boray, 1999. Fasciolicides: efficacy, actions, resistance and its management. Vet. J., 158: 81-112. PMID: 10489266

Guerrero, J., F.B. Michael, M.W. Rohovsky and B.P. Campbell, 1983. The activity of closantel as an equine antiparasitic agent. Vet. Parasitol., 12: 7177. PMID: 6683040

Lanusse, C., A. Lifschitz, G. Virkel, L. Alvarez and S. Sanchez et al., 1997. Comparative plasma disposition kinetics of ivermectin, moxidectin and doramectin in cattle. J. Vet. Pharmacol. Ther., 20: 91-99. PMID: 9131534

Lanusse, C.E. and R.K. Prichard, 1993. Relationship between pharmacological properties and clinical efficacy of ruminant anthelmintics. Vet. Parasitol., 49: 123-158. PMID: 8249240
Lifschitz, A., A. Pis, L. Alvarez, G. Virkel and S. Sanchez et al., 1999a. Bioequivalence of ivermectin formulations in pigs and cattle. J. Vet. Pharmacol. Ther., 22: 27-34. PMID: 10211714

Lifschitz, A., G. Virkel, A. Pis, F. Imperiale and S. Sanchez et al., 1999b. Ivermectin disposition kinetics after subcutaneous and intramuscular administration of an oil-based formulation to cattle. Vet. Parasitol., 86: 203-215. DOI: 10.1016/S03044017(99)00142-9

Lifschitz, A., J. Sallovitz, F. Imperiale, A. Pis and J. Lorda et al., 2004. Pharmacokinetic evaluation of four ivermectin generic formulations in calves. Vet. Parasitol., 119: 247-257. PMID: 14746983

Lo, P.K.A., D.W. Fink, J.B. Williams and J. Blodinger, 1985. Pharmacokinetic studies of ivermectin: effects of formulation. Vet. Res. Commun., 9: 251268. DOI: $10.1007 / \mathrm{BF} 02215150$

Michiels, M., W. Meuldermans and J. Heykants, 1987. The metabolism and fate of closantel (Flukiver) in sheep and cattle. Drug Metab. Rev., 18: 235-251. PMID: 3330516

Mohammed-Ali, N.A.K. and J.A. Bogan, 1987. The pharmacodynamics of the flukicidal salicylanilides, rafoxanide, closantel and oxyclosanide. J. Pharmacol. Ther., 10: 127-133. DOI: 10.1111/j.1365-2885.1987.tb00089.x

Montenegro, Y.V., F.I. Velarde, H.Q. Romero, A.H. Campos and R. Castillo, 2003. Field trial on the efficacy of an experimental fasciolicide compared with some commercial compounds in naturally infected cattle. Parasitol. Res., 91: 1-4. DOI: 10.1007/s00436-003-0901-y

Mooney, L., B. Good, J.P. Hanrahan, G. Mulcahy and T.D. Waal, 2009. The comparative efficacy of four anthelmintics against a natural acquired fasciola hepatica infection in hill sheep flock in the west of Ireland. Vet. Parasitol., 164: 201-205. DOI: 10.1016/j.vetpar.2009.05.017

Mwamachi, D.M., J.O. Audho, W. Thorpe and R.L. Baker, 1995. Evidence for multiple anthelmintic resistance in sheep and goats reared under the same management in coastal Kenya. Vet. Parasitol., 60: 303-313. PMID: 8747913

Sallovitz, J., A. Lifschitz, F. Imperiale, A. Pis and G. Virkel et al., 2002. Breed differences on the plasma availability of moxidectin administered pour-on to calves. Vet. J., 164: 47-53. PMID: 12359484

Sivaraj, S., P. Dorny, J. Vercruysse and V.S. Pandey, 1994. Multiple and multigeneric anthelmintic resistance on a sheep farm in Malaysia. Vet. Parasitol., 55: 159-165. DOI: 10.1016/03044017(94)90068-X 
Stromberg, B.E., J.C. Schlotthauer, B.P. Seibert, G.A. Conboy and K.M. Newcomb, 1985. Activity of closantel against experimentally induced Fascioloides magna infection in sheep. Am. J. Vet. Res., 46: 2527-2529. PMID: 4083587

Toutain, P.L. and G.D. Koritz, 1997. Veterinary drug bioequivalence determination. J. Vet. Pharmacol. Ther., 20: $\quad 79-90$. DOI: $10.1046 /$ j.13652885.1997.00047.x

Toutain, P.L., D.W. Upson, T.N. Terhune and M.E. McKenzie, 1997. Comparative pharmacokinetics of doramectin and ivermectin in cattle. Vet. Parasitol., 72: 3-8. DOI: 10.1016/S03044017(97)00070-8
Toutain, P.L., M. Campan, P. Galtier and M. Alvinerie, 1988. Kinetic and insecticidal properties of ivermectin residues in the milk of dairy cows. J. Vet. Pharmacol. Ther., 11: 288-291. DOI: 10.1111/j.1365-2885.1988.tb00155.x PMID: 3184269

Uppal, R.P., C.L. Yadav and C. Bhushan, 1993. Efficacy of closantel against fenbendazole and levamisole resistant Haemonchus contortus in small ruminants. Trop. Anim. Health Prod., 25: 3032. DOI: 10.1007/BF02236883 PMID: 8465440

Vercruysse, J. and R.S. Rew, 2002. Macrocyclic Lactones in Antiparasitic Therapy. 1st Edn., CABI, Wallingford, UK., ISBN: 0851996175, pp: 432. 